\title{
VÝVOJ KULTURNÍ POLITIKY HLAVNÍHO MĚSTA PRAHY PO ROCE 2001
}

Vývoj kulturní politiky v hlavním městě Praze byl a je složitým a stále nekončícím procesem. O nezbytnosti definovat strategické cíle v oblasti kulturní politiky, která má dopad na téměř všechna umělecká odvětví, snad už není pochyb. Dopracovat se právě k takovému postoji bylo jedním z úkolů části kulturní a odborné veřejnosti, která se ve vývoji kulturní politiky angažovala. A bylo nutné přesvědčit nejen politiky, ale i část veřejnosti v kultuře pưsobící. Hlavním hnacím motorem se stala právě vzájemná interakce obou skupin motivovaná snahou změnit stávající systém financování kultury a zároveň nastavit podmínky pro vytvoření optimálního prostředí, které otevírá prostor pro vznik nových kvalitních projektů, stejně jako pro zánik projektů neúspěšných či vyčerpaných. $Z$ těchto snah vykrystalizovala tři velká vzájemně propojená témata: kulturní politika hl. m. Prahy, grantová politika hl. $\mathrm{m}$. Prahy (následně zakotvené v dokumentech) a transformace príspěvkových organizací, kterou se ale tato studie zabývat nebude. Dovolím si tedy krátký historický exkurz do vývoje dokumentů.

Koncepce kulturni politiky hl. m. Prahy a Grantová politika hl. m. Prahy byly schváleny $\mathrm{v}$ červnu roku 2006. Jejich vznik podnítila nespokojenost kulturní veřejnosti vyvolaná netransparentními praktikami $\mathrm{v}$ některých formách financování kultury z městského rozpočtu, zejména v udělování grantů a spolupořadatelství (později partnerství).

\section{Financování kultury}

Jak vypadal systém financování kultury v Praze před vytvořením strategických dokumentů? Hl. m. Praha poskytovalo na kulturu ročně přibližně $5 \%$ svého rozpočtu a to několika formami: investiční a neinvestiční př́spěvky př́spěvkovým organizacím, finanční př́spěvky městským částem (napřs. na opravy soch, památníků, rekonstrukce objektů atd.), dále dary a kulturní a umělecké ceny. Zásadními metodami financování kulturních institucí, kromě př́spěvkových organizací, bylo tzv. spolupořadatelství a grantový systém. Spolupořadatelstvím 
poskytovalo město finanční podporu významným festivalům, přehlídkám, soutěžím atd. O jeho udělení rozhodoval Výbor pro kulturu magistrátu hl. m. Prahy (dále MHMP). Nebyla stanovena žádná kritéria a hodnocení se neúčastnili odborníci. A právě z těchto důvodů byla forma spolupořadatelství soustavně kritizována.

Granty v oblasti kultury hlavní město vypisuje od roku 1995 (resp. na rok 1996), ${ }^{1}$ tématicky určené na podporu profesionální divadelní, hudební, taneční, výstavní a ediční činnosti a dále na reprezentaci kultury v zahraničí. Podporu mohly získat také subjekty i samostatné projekty z oblasti neprofesionálního umění (zájmové skupiny a soubory). Př́íspěvkové organizace se grantového řízení ze zákona účastnit nemohou. Žádosti posuzovali dva externí odborníci, kteří grantové komisi vypracovali doporučení (nezveřejňovaná), nicméně ta pro ni nebyla závazná. Hodnocení odborníků nebyla bodově odstupňovaná a spočívala pouze ve vyjádření $+/-$, tedy ano/ne. Částky jednotlivým projekti̊m přidělovala grantová komise. Neměla ovšem povinnost svá rozhodnutí zdůvodňovat. Návrhy komise projednával výbor pro kulturu a následně (stejně jako v současnosti) je schvalovala Rada hl. m. Prahy (granty do 200000 Kč) a Zastupitelstvo hl. m. Prahy (granty nad $200000 \mathrm{Kč}$ ). ${ }^{2}$

\section{Kultura ve strategických dokumentech}

Do doby než byl formulován první dokument věnující se výhradně kulturní politice můžeme sledovat určité zmínky a náznaky strategií kulturní politiky v několika dokumentech - Strategický plán rozvoje hl. m. Prahy, Programové prohlášení Rady hl. m. Prahy a výroční zprávy Kultura v Praze odboru kultury a výstavnictví MHMP.

Koncept Strategického plánu hl. m. Prahy byl schválen radou roku 1998 a ta z něj vycházela v dokumentu Programové prohlášení na léta 1998-2002. ${ }^{3}$ Plán měl poskytnout koncepční rámec při rozhodovacích procesech zastupitelských orgánů a pomoci postupně naplňovat stanovené dlouhodobé cíle a strategickou vizi města. ${ }^{4} \mathrm{Z}$ obou dokumentů můžeme velice dobře pozorovat postoj tehdejší politické reprezentace. Strategické cíle v oblasti kultury se často omezovaly pouze na ochranu kulturního dědictví. Lze říci, že šlo o jakési paradigma kulturní politiky devadesátých let, které doznívalo ještě v prvních letech nového tisícile-

1 Usnesení Rady Zastupitelstva hl. m. Prahy č. 1402 ze dne 12. 12. 1995 [online]. [cit. 201503-12]. Dostupné z:http://rada.praha.eu.

2 Dle Usnesení rady Zastupitelstva hlavního města Prahy č. 959 ze dne 7. 9.1999 [online]. [cit. 2015-03-12]. Dostupné z: http://rada.praha.eu.

3 Usnesení rady Zastupitelstva hlavniho města Prahy č. 234 ze dne 23. 2. 1999 [online]. [cit. 2015-03-12]. Dostupné z: http://rada.praha.eu.

4 Strategický plán hl. m. Prahy [online]. In: ENVIS - informační servis. 1999, s. 22, [cit. 2015-02-14]. Dostupné z: http://envis.praha-mesto.cz/\%28bm4grrjcztvnq545qbpbfp45\%29/ default.aspx clc $=\& I d o=5278 \&$ sh $=-1294051557$ 
tí. Obecně byla kultura vnímána spíše jako ekonomická příležitost a nástroj pro rozvoj cestovního ruchu. Jen okrajově se připouštělo, že slouží také samotným občanům a má i další přesahy. Nicméně, ačkoli se kultuře přiznávaly jisté ekonomické př́nosy, prostředky na její rozvoj stále nebyly chápány jako investice, ale jako nenávratné dotace. Změnit tento pohled bylo jedním z úkolů odborné a kulturní veřejnosti.

\section{Témata a diskuze ke kulturní politice}

Rok 2003 byl rokem debat nad aktuálními otázkami kulturní politiky. I před tím se vedly diskuze, ale rok 2003 zažil enormní koncentraci. Debaty se odehrávaly po celé České republice např. Stát pro umění 21. století, Respektování v Brně, sympozium Kultura a společnost, společnost a kultura, Stát - Město Kultura, semináŕ Transformace divadelního systému. Mimo to vláda schválila Program podpory profesionálnich divadel a orchestrü ${ }^{5}$ a navrhla věcný záměr zákona o podpoře kultury. ${ }^{6}$ Mezi základní témata patřily otázky legitimity podpory kultury z veřejných rozpočtů, možnosti uzákonění alternativních zdrojů např. daňové asignace, podnícení zatím nedostatečné motivace soukromých mecenášů, stanovení nástrojů a kritérií a rozdělení kompetencí politiků a odborníků při udělování finanční podpory. Zejména na posledně jmenovaném tématu bylo zajímavé sledovat postoje politických představitelů, např. u bývalého primátora Pavla Béma. Podle něj je totiž neoddiskutovatelné, že na začátku i na konci celého procesu má stát politická reprezentace. Nejdř́ve získá peníze do rozpočtu a rozhodne kolik půjde na granty a kolik na př́íspěvkové organizace. Poté přijdou na řadu odborníci. V této souvislosti se ale otevřela také delší dobu diskutovaná otázka role „nezávislého odborníka“, který má v grantovém systému figurovat. Bém tuto „nezávislost““ zpochybňoval, protože ve své profesní oblasti jsou všichni nějak ,závislí“. 7 Tento fakt ale zástupci odborné veřejnosti nepopírali. To, že se např. v divadelním prostředí všichni se všemi znají a nezávislost tedy není možná, zdůraznila Doubravka Svobodová. ${ }^{8}$ A právě proto je důležité oficiálně stanovit kritéria, kterými se odborníci budou řídit a která do určité míry eliminují osobní zájmy.

$5 \quad$ Usnesení Vlády ČR ze dne 10. záři 2003 č. 902 o Programu státni podpory profesionálních divadela profesionálních symfonických orchestrů a pěveckých sbori̊ [online]. 10. 9. 2003, [cit. 2015-04-16]. Dostupné z: www.mkcr.cz/assets/umeni/Usnesen_vl_dy_-902.doc. Záměr byl schválen 28. 4. 2004.

7 STÁT-MĚSTO - KULTURA: souhrn příspěvků otevřené diskuze, kterou uspořádalo hl. $\mathrm{m}$. Praha ve spoluprácis Ministerstvem kultury ČR [online]. Ed. Mgr. Martin Kupka. Praha, Divadlo Archa: 1. 1. 2004, s. 9. [cit. 2014-06- 05] Dostupné z: http://host.divadlo.cz/box/ clanek.asp?id=5418.

Toho času ředitelka Divadla Na zábradlí. 
Na vizi Bémova modelu reagoval Robert Palmer. ${ }^{9}$ Uvedl, že politická reprezentace nemá rozhodovat o konkrétní finanční podpoře. Měla by stanovovat cíle a strategie kulturní politiky. Protože kulturní systém je složitý, rozhodnutí by se měla odehrávat v kruhu odborníků, kteří poskytnou různé pohledy a hodnocení. Takový model ale politici v čele s primátorem Bémem odmítali.

K určitému konsenzu v rámci diskuzí přeci jen došlo a závěry zněly jednoznačně: Je třeba zformulovat strategii kulturní politiky za účasti odborné veřejnosti na úrovni státu, krajů a obcí. Je nezbytné vytvořit rovné podmínky pro všechny subjekty podílející se na poskytování veřejných kulturních služeb jednak posílením podílu grantové metody financování a za druhé systémem hodnocení nebo ověřování kvality a užitečnosti nabídky kulturních institucí a zvážit také možnost jejich kategorizace pro potřeby financování. Dále vyhledávat nové mimorozpočtové zdroje podpory kultury a v systému financování kultury vytvořit podmínky pro větší podporu živého umění a podporu začínajících umělců.

$\mathrm{K}$ reálným změnám ale došlo až v souvislosti s vyhrocenými okolnostmi netransparentního udělování grantů.

\section{Čtyři body pro kulturu}

Na podzim roku 2004 byly vyhlášeny výsledky grantového řízení. Navrhovaná výše některých grantů vyvolala velkou nevoli umělecké veřejnosti a následně na žádost předsedy výboru pro kulturu byl návrh stažen z jednání zastupitelstva, které zasedalo 21. 10. 2004. V reakci na celou situaci s grantovým ř́zením vznikla iniciativa umělců, později pojmenovaná 4 body pro kulturu.

Sporným př́padem byl udělený grant společnosti ART FRAME PALÁC AKROPOLIS s.r.o. V oblasti čtyřletých grantů na léta 2005-2008 se obyčejně pohybovaly částky nejvyšších dotací na rok ve výši 5-8 milionů. Palác Akropolis obdržel čtyřletý grant na první rok ve výši 15 mil., na druhý rok 16 mil. a na dvě zbývající léta ve výši 17 mil. Kč. ${ }^{10}$ Ve spojitosti s dotacemi tomuto subjektu z pražského rozpočtu se dostával do střetu zájmů zastupitel ODS Pavel Hurda, vlastník objektu, kde Palác Akropolis sídlí. Tato kauza upozornila také na pozoruhodné rozdíly mezi doporučením grantové komise a částkou přidělenou Radou hl. m. Prahy. Napřs. doporučená částka 5 mil. Kč Divadlu Bez zábradlí byla radou

9 Robert Palmer je zakladatelem celé řady kulturních institucí ve Velké Británii. Působil jako divadelní ředitel, ministr kultury Skotska a jako radní pro kulturu v Glasgow. V roce 1990 vedl také projekt Hlavní město kultury v Glasgow a v roce 2000 shodný projekt v Bruselu. V současné době působí jako konzultant $\mathrm{v}$ oblasti kultury pro instituce Evropské unie a pro samosprávy mnoha významných měst jako jsou např́klad Barcelona, Marseille, Rotterdam, Belfast či Budapešt'. (Zdroj: Souhrn př́spěvků Stát - město - kultura, připravil Mgr. Martin Kupka).

10 Př́loha č. 1 k usnesení Rady hl. m. Prahyč. 1707 ze dne 12. 10. 2004 [online]. [cit. 2015-0310]. Dostupné z:http://rada.praha.eu. 
zvýšena na 8 mil. Kč, u Paláce Akropolis byla navrhovaná částka 10 mil. zvýšena návrhem rady na 15 mil. Kč. ${ }^{11}$

Kromě této záležitosti iniciativa 4 body pro kulturu vystoupila i s tím, že štědré čtyřleté granty byly poskytovány na úkor jednoletých grantů. Vzniklo podezření na netransparentnost celého grantového řízení. Iniciativa 4 body pro kulturu tedy vznesla na zasedání zastupitelstva požadavky:

1. ,projednat čtyřleté granty v přimé souvislosti s jednoletými

2. vytvořit expertni skupinu pro posouzení všech žádostí o čtyřletý grant

3. prítomnost odborníki na jednáních komise Rady pro udílení granti̊ v oblasti kultury,

4. prozkoumání všech žádostí o čtyřleté granty kontrolním výborem ZHMP, zda jsou v souladu s podminkami grantového řizení."12

Prosadit schválení požadavků na zasedání zastupitelstva dne 25. 11. 2004 se nepodařilo ani představitelce iniciativy Yvoně Kreuzmannové. Chybějící politická vůle ke změně dotačního systému a opomíjení všech požadavků donutily iniciativu dne 9. 12. dopisem vyzvat radního Igora Němce, aby byly učiněny patřičné kroky. Po mnoha apelech byl v lednu 2005 splněn jeden z požadavků udělit čtyřleté granty jako jednoleté. Mimo to byly částky dotací sníženy. Projektu na provoz Paláce Akropolis společnosti ART FRAME byla navržena stále výrazně vyšší částka $9.400 .000 \mathrm{Kč}$ a $\mathrm{k}$ tomu v grantovém tématu na zahraniční spolupráci ještě 350.000 Kč.

Ještě v prosinci 2004 vypracovala iniciativa 4 body pro kulturu analýzu grantového řízení hl. m. Prahy s návrhem na vylepšení, která by měla eliminovat zmíněné problémy (tedy odbornost rozhodování, transparentnost a vyloučení politické lobby). ${ }^{13}$ Po podzimní kauze s grantovým řízením primátor Pavel Bém slíbil uspořádat diskuze k problematice dotačního systému a kulturní politiky Prahy, které se následně uskutečnily ve třech termínech začátkem roku 2005.

Z diskuzí vzešly následující závěry:

- Bude zpracována Koncepce kulturní politiky hlavního města Prahy. Její návrh vytvoř́i pracovní skupina č. 1 složená z teoretiků z kulturní oblasti, zástupců pražských kulturních organizací, zástupců hlavního města Prahy s dohledem zahraničních experti̊. Koncepci projedná zastupitelstvo do konce roku.

- Pracovní skupina č. 2 (tvořená podobným způsobem jako první) bude zpracovávat nový grantový systém. Ten zahrnuje definování nových grantových oblastí, doplnění odborníků z kulturní, ekonomické a právní oblasti do grantové komise, zavedení diskuze odborníků nad všemi grantovými žádostmi. Pokud se grantová komise odkloní od stanoviska odborníků, bude povinnost tento

11 Ibid.

12 Otevřený dopis: Členům výboru kultury Zastupitelstva a ostatním zastupitelům [online]. [cit. 2015-03-19]. Dostupné z: http://www.proculture.cz/cultureinfo/kulturni-politika-v-cr/praha/ iniciativa-prazske-kulturni-sceny- usili-o-zmenu-navrhu-4-letych-grantu-mesta-prahy-pokracuje-510.html.

13 Analýza grantového řizení hl. m. Prahy pro oblast kultury [online]. In: Divadlo.cz. 26. prosince 2004, [cit. 2015-07- 26]. Dostupné z: http://host.divadlo.cz/art/clanek.asp?id=7123. 
krok zdůvodnit. Musí nastat změna stávajícího hodnocení (ano/ne, resp.+/-) na bodové. U čtyřletých grantů je nutné zavést povinnost předložit závěrečnou zprávu o hospodaření včetně dalších informací (např. návštěvnost), zavést veřejná slyšení u žádostí o čtyřletý grant, rozlišit provozní náklady a náklady na činnost a stanovit maximální procentní částku, kterou může být projekt financován z veřejných zdrojů (EU, stát, město).

- Dokončení transformace př́íspěvkových organizací, která povede k efektivnímu hospodaření a větší samostatnosti kulturních organizací.

\section{Iniciativa pro kulturu}

Po měsíci a půl, kdy se opět nerýsovaly žádné změny a zastupitelstvo mělo jednat o čtyřletých grantech (na léta 2006-2009), které navrhovala grantová komise v nezměněném složení, se zástupci kulturní veřejnosti odhodlali k dalšímu kroku. Na 31. 3., kdy mělo zastupitelstvo jednat, vyzvali veřejnost ke shromáždění před budovou magistrátu a uspořádali happening „Ukřižování pražské kultury“. Pořadatelem shromáždění byla nově vzniklá Iniciativa pro kulturu založená především představiteli neformálního sdružení 4 body pro kulturu, dále Divadlem bratří Formanů, divadly Archa, Alfred ve dvoře, v Celetné, Tancem Praha a dalšími 30 subjekty.

Dne 22. 4. 2005 jmenoval primátor dvě slibované pracovní skupiny: č. 1 Pracovní skupina primátora hlavního města Prahy pro vytvoření koncepce kulturní politiky hlavního města Prahy, č. 2 Pracovní skupina primátora hlavního města Prahy pro optimalizaci grantového systému hlavního města Prahy v oblasti kultury. Členové, delegovaní z řad odborníků působících napříč kulturními žánry, byli nominováni uskupením Iniciativa pro kulturu a sdružením FUTURE CULTURE (kterou tvořila část kulturní veřejnosti zastávající odlišný názorový směr než Iniciativa pro kulturu). Pracovní skupiny byly později sloučeny do Poradního sboru primátora pro kulturu.

Iniciativě pro kulturu se podařilo již do grantového řízení na rok 2006 prosadit několik nových zásad. Poprvé v historii se např. konala veřejná slyšení žadatelů o čtyřletý grant na rok 2006. Poprvé také rozhodovala komise složená jak ze zástupců politické reprezentace a úředníků, tak z odborné veřejnosti. Sice nebyl vyslyšen požadavek, aby měly své zástupce v komisi všechny umělecké obory (např. hudba odborného zástupce $\mathrm{v}$ komisi neměla), ale prrítomnost odborníků měla svůj prínos v otevření diskuze a nabídnutí nových pohledů při hodnocení projektů. Nicméně většinu v komisi měli politici a ve sporných kauzách mohli být odborníci prèlasováni. A tak výsledky grantového rízení stále vyvolávaly otázky transparentnosti a nastavení celého systému. Př́padným stížnostem divadelníků na udělení dotací společnosti ART FRAME PALÁC AKROPOLIS s.r.o se předešlo tím, že byl tento projekt přesunut z oblasti divadelní do hudební. Tam byl následně navýšen rozpočet, a tak Palác Akropolis dostal dotaci, která v té době neměla v hudební oblasti obdoby -13.500 .000 Kč. Přes protesty kulturní a odborné veřejnosti, výsledky zpochybněny nebyly. 
Iniciativa pro kulturu v roce 2006 poprvé upozornila na problematiku přidělování dotací veřejné podpory $\mathrm{v}$ režimu de minimis, tj. že veřejná podpora obchodním společnostem nesmí přesáhnout hranici 200 tisíc euro za dobu tří po sobě jdoucích let. ${ }^{14}$ Těmto nařízením Praha začala podléhat vstupem ČR do Evropské unie v roce 2004. Jak se později ukázalo, bylo velkou chybou, že tuto připomínku město nereflektovalo.

\section{První dokumenty ke kulturní politice Prahy}

Dokumenty ke grantové a kulturní politice připravené v říjnu 2005 byly schva'leny zastupitelstvem 29. června 2006. ${ }^{15}$ Koncepce kulturni politiky se stala prvním strategickým dokumentem v oblasti kultury hl. m. Prahy. Prověřit praxí je měl až rok 2007.

Koncepce kulturni politiky hl. m. Prahy ${ }^{16}$ se zabývá pěti okruhy: Teoretická východiska, Analýza situace v Praze, Dlouhodobé zásady kulturní politiky města Prahy, Střednědobá koncepce kulturní politiky Prahy, Nástroje kulturní politiky. Vznikl otevřený dokument, po kterém kulturní veřejnost čím dál intenzivněji volala. Předložená strategie totiž poskytovala kritéria, podle kterých se měla orientovat podpora kulturních projektů. Nadějným příslibem se stalo zachování minimálně stejného objemu financí na kulturu. Za prínos lze považovat také definování pojmů, které byly i v následujících letech používány (i zneužívány). Autoři se rozhodli nepracovat s formulacemi komerční/nekomerční a proto, že nevypovídají nic o umělecké hodnotě.

Grantová politika hl. m. Prahy v oblasti kultury a uměni $i^{17}$ charakterizuje základní principy následovně: Formou grantu mohou být podporované kulturní aktivity neziskových organizací, kulturních institucí a fyzických i právnických osob. O grant mohou žádat subjekty provozující uměleckou činnost na území hl. m. Prahy a jsou registrovány dle platných právních předpisů ČR. Na jeden projekt není možné žádat $\mathrm{v}$ rámci dalších oblastí grantového systému hl. m. Prahy. Z grantů mohou být pokryty jen ztrátové náklady projektu, prostředky nelze použít za účelem zisku. Při hodnocení grantu nerozhoduje právní forma žadatele, především se hodnotí soulad projektu s cíli kulturní politiky hl. m. Prahy, realizovatelnost projektu a přiměřenost nákladů. Doporučeným hlediskem je

Smlouvy o ES - články 87 a 88. Dostupné z: https://www.uohs.cz/cs/verejna-podpora/podpora-de-minimis.html.

15 Podrobnější rozbor obou dokumentů viz ŠMÍDOVÁ TURCHICHOVÁ, Magdalena. Vývoj kulturní politiky v hl. m. Prahy po roce 2001. Brno, 2015. Diplomová práce. Masarykova univerzita. Fakulta filozofická. Vedoucí práce doc. Ing. František Svoboda, Ph.D. Dostupné online: http://is.muni.cz/th/180098/ff_m/.

Přiloha č. 1 k usnesení Zastupitelstva hlavního města Prahy č. 39/19 ze dne 29. 6. 2006 [online]. [cit. 2015-07-21] Dostupné z: http://zastupitelstvo.praha.eu.

17 Př́loha č. 2 k usnesení Zastupitelstva hlavního města Prahy č. 39/19 ze dne 29. 6. 2006 [online]. [cit. 2015-07-21]Dostupné z: http://zastupitelstvo.praha.eu. 
zajištění vícezdrojového financování. Grantová komise je jmenována z nezávislých odborníků a zástupců MHMP. Hodnocení žádostí probíhá ve dvou kolech. Daný projekt posuzuje vždy dvojice členů (většinou jeden odborník dle dané oblasti projektu a jeden politický představitel), která pak ve shodě (ne)doporučuje celé grantové komisi udělení grantu a minimální výši částky. K posuzování žádostí si členové grantové komise mohou vyžádat externí posudky.

Ani v Koncepci kulturní politiky ani v Grantové politice hl. m. Prahy není zakotveno pravidlo o poskytování dotací v režimu de minimis, na které již upozorňovala Iniciativa pro kulturu.

\section{Dotace na vstupenku}

Oba dokumenty následně prošly několika aktualizacemi a to dřív než se předpokládalo. Vlivem vyhrocených okolností v roce 2007, kdy nový radní pro kulturu Milan Richter zavedl nekoncepční opatření, došlo v grantovém systému opět ke komplikacím. Situace vznikla udělením grantů dle zastupitelstvem schválené grantové politiky, kdy se cítili znevýhodněni především majitelé soukromých divadel - Divadlo na Jezerce Jana Hrušínského, Divadlo Kalich Janka Ledeckého, Ta Fantastika Petra Kratochvíla a Divadlo Radka Brzobohatého -, která v žádostech o čtyřleté granty neuspěla. Jejich představitelům se nelíbilo, komu komise grant přidělila, ani samotná kritéria hodnocení grantů, což veřejně deklarovali. Proto radní svolal diskuzi s „,poškozenými“ divadly. Zúčastnila se jich ale i Inciativa pro kulturu. Stížnostem nespokojených divadel, že grantová komise pracuje subjektivně, dal radní za pravdu (šlo o grantovou komisi, kterou sám jmenoval). A opět se otevřela poněkud vyostřená diskuze, jak má grantový systém hl. m. Prahy vypadat. Iniciativa pro kulturu mimo jiné připomněla také nedodržování pravidla de minimis. Bohužel právě tento argument roztočil další kolo událostí, jež grantový systém ovlivnily. V srpnu roku 2007 totiž Petr Kratochvíl podal žalobu k Evropské komisi a mezinárodnímu arbitrážnímu soudu na český stát a to ze dvou důvodů. Stát neochránil jeho investice (jako občana USA), a také kvưli pravidlům financování pražských divadel, zejména porušování pravidla de minimis. Ačkoli připomínky odborné veřejnosti ke kulturní a grantové politice byly za poslední léta přijímány magistrátem poměrně laxně, tentokrát Rada hl. m. Prahy zareagovala velice hbitě. Okamžitě totiž pozastavila granty na následující rok (nikoli však rozdělování peněz prostřednictvím partnerství). Je otázkou, zda tím neuznala stížnost Petra Kratochvíla za oprávněnou ještě dříve, než bylo známo stanovisko soudu. Nebylo zcela jisté, že Petr Kratochvíl s žalobou uspěje. Existovala totiž možnost vypracovat pro Evropskou komisi k uděleným grantům odborné posudky, na základě kterých by byly žádosti dodatečně notifikovány. Radní ovšem samotnou situaci s žalobou neřešil, za to prrišel s preventivním řešením a od rady si nechal zadat aktualizaci obou dokumentů, tedy Grantové i Kulturní politiky.

Koncepce kulturní politiky tak došla drobných změn. Nově bylo ustanoveno dodržování pravidla de minimis. Vstř́íným krokem se také mohlo zdát ustano- 
vení grantové komise z odborníků, které se ale později nejevilo jako jednoznačně pozitivní $\mathrm{z}$ důvodu velkého politického tlaku ze strany radního. Richter dále přišel s novým čtyřpilíŕovým grantovým systémem, což nebylo nic jiného než poněkud křečovitá implementace plošné nárokové dotace na vstupenku do stávajícího grantového systému. Na úskalí formy dotace na vstupenku upozorňovala i vedení některých divadel. Tento způsob financování totiž nutně musí vést k podbízivému repertoáru, jediným hlediskem se stane maximalizace návštěvnosti třeba i na úkor umělecké kvality. „Je to úplné popření uměleckého rozměru divadla. Úspěch komerčni neznamená ještě úspěch umělecký. “18 shodli se ředitelé divadel Vladimír Procházka z Činoherního klubu a David Jařab z Divadla Komedie. Navíc, když odhlédneme od divadelní oblasti, např. některé galerie do této grantové kategorie vůbec nebudou moci vstoupit, protože mají vstupné nižší než minimálně stanovených $150 \mathrm{Kč}$, některé instituce mají vstup úplně zdarma.

První problémy s novým čtyřpilírovým grantovým systémem se objevily už ve chvíli, kdy podle něj začala pracovat grantová komise, která zjistila, že pro první grantovou skupinu - dotaci na vstupenku nebyl navýšen rozpočet, ba dokonce ani ve skupině víceletých grantů se, vzhledem k závazkům z předchozích let, peněz nedostává. Po mnoha tahanicích mezi grantovou komisí, která navrhovala snížit daný objem financí pro dotaci na vstupenku ve prospěch víceletých grantů, a politickými představiteli, kteří tento návrh nejprve tvrdošíjně odmítali, byl následně deficit dorovnán alespoň tak, aby město dostálo smluvním závazkủm u již udělených čtyřletých grantů. Na poskytnutí nových čtyřletých grantů ale prostředky nezbyly.

Dotace na vstupenku měla očekávaný efekt. Divadlo Ta Fantastika Petra Kratochvíla obdrželo 5,6 milionu Kč (když sečteme všechny prostředky, které obdržel i v rámci partnerství, dostává se daleko za hranici pravidla de minimis). Uspokojením požadavků soukromých divadel dotací na vstupenku se totiž, jak se dalo předpokládat, nedostalo na tradiční festivaly a projekty, které jsou dokonce zmíněné v Koncepci kulturní politiky jako reprezentativní projekty. Bez podpory zůstaly Dny evropského filmu, Tanec Praha nebo 4 dny v pohybu. U festivalu Tanec Praha je navíc pikantní fakt, že se jím Česká republika prezentovala v programu u př́ležitosti předsednictví Evropské unie na následující rok.

Po obdržení grantu Petr Kratochvíl nakonec ustoupil od žaloby (přesto, že mu šlo o princip a ne o peníze, jak prohlašoval) a dne 12. února 2008 byla podepsána Dohoda o narovnáni mezi Ministerstvem financí a panem Petrem Kratochvílem. Dohoda neobsahovala žádné podmínky finanční kompenzace. Ministr Kalousek se následně obrátil na primátora Pavla Béma s prosbou, aby grantové politice hl. m. Prahy věnoval nejvyšší pozornost. ${ }^{19}$

18 ČECHLOVSKÁ, Magdalena - NEPRAŠOVÁ, Veronika. Spor o granty poškozuje i nevinné neziskovky [online].In: Hospodářské noviny. 7. zárí 2007, [cit. 2015-02-05]. Dostupné z: http://archiv.ihned.cz/c1-21972400-spor-o-granty-poskozuje-i-nevinne-neziskovky.

19 MACHALICKÁ, Jana. Arbitráž kvůli divadli̊m nebude. Lidové noviny. 14. února 2008, s. 19. 
Amatérismus v kulturní politice radní Richter završil naplánováním překotné a nepřipravené transformace divadel, absolutní neochotou komunikovat s odbornou veřejností, kontinuálním vyplácením milionových částek v režimu partnerství, ale také proslulou výrobou klipu pro nalákání turistů do Prahy za 8,5 mil. Kč. Reakce veřejnosti vyvrcholily peticí Za Prahu kulturní (podepsalo ji přes 30000 lidí) a dubnovým shromážděním občanů před budovou magistrátu. V květnu následovaly celorepublikové Dny neklidu, které měly upozornit na problematiku kulturní politiky ČR.

Do takto vyhrocené situace vstoupil primátor Pavel Bém. S radním Richterem vydali prohlášení, ve kterém přistoupili na některé požadavky petice. Především byl opět ustanoven Poradní sbor primátora pro oblast kulturní a grantové politiky. K hlavním úkolům patřilo vypracování aktualizace kulturní politiky a nového grantového systému a to do konce října 2008, aby mohlo být vyhlášeno grantové řízení na rok 2009.

\section{Aktualizace dokumentů ke kulturní politice}

Po několikaměsíční práci poradního sboru schválilo zastupitelstvo dne 18. 6 . 2009 dokument Grantový systém hl. m. Prahy na léta 2010-2015. ${ }^{20}$ Inovovaný dotační model obsahoval následující principy:

- „na poskytnutí grantu není právní nárok

- grant může být poskytnut maximálně do výše vyrovnaného rozpočtu projektu

- grantový systém je otevřený všem subjektům bez ohledu na právní formu existence

- víceletý grantový model pracuje se stejnými hodnotícími kritérii při posuzování žádostí jako jednoletý model, jen s adekvátně detailnějši strukturou hodnoticich parametri

- grantové prihlášky ve všech kategoriich posuzuje jedna grantová komise

- bodový systém hodnocení

- zdiovodněni rozhodnutí Grantové komise

- oznámení o výsledcích grantového ř́zení je konečné a nelze se proti němu odvolat."

O půl roku později dne 3. 2. 2010 byla výborem pro kulturu doporučena také aktualizovaná verze Koncepce kulturní politiky hl. m. Prahy, kterou zpracoval Poradní sbor primátora ve spolupráci s Odborem kultury a památkové péče

20 Př́loha č. 1 usnesení Zastupitelstva hl. m. Prahy č. 28/43 ze dne 18. 6. 2009 [online]. [cit. 2015-02-25]. Dostupné z: http://zastupitelstvo.praha.eu. 
MHMP. ${ }^{21}$ Zastupitelstvo dokument odsouhlasilo dne 3. 6. 2010. ${ }^{22}$ Koncepce je aktualizovanou verzí dokumentu z roku 2006 a jsou do ní implementována hlediska, ke kterým přihlíží a jež uplatňuje Evropská unie. Kromě cílů a priorit uvedených v dokumentu z roku 2006 jsou specifikovány na léta 2010-2015 především:

- „Podpora nejširšího spektra umělecké tvorby a kultury v rámci nového dotačního systému HMP

- Provedení druhé etapy transformace př́spěvkových organizací HMP v oblasti kultury.

- Evaluace nového dotačního systému HMP a jeho finanční zajištění. Zejména pak vymezeni sfér vlivu mezi grantovým systémem a partnerstvím HMP

- Rozvoj vícezdrojového financováni pražské kultury a uměni"'23

Poslední aktualizace Koncepce kulturni politiky hl. m. Prahy s platností do roku 2015 byla schválena 3. 6. 2010. Proces schválení Grantové politiky hl. m. Prahy se připomínkami prodloužil a odsouhlasen byl až 17. 2. 2011. Evropská komise dokument notifikovala 15. 6. 2011.

\section{Závěrem}

Vývoj kulturní politiky nebyl jednoduchý, ale jeho dynamický proces se ukázal jako nezbytný. V systému, kde jsou rozdělovány nikoliv neomezené finanční prostředky, je nutné nejen stanovit preferované cíle, ale také kritéria, která pomohou prostředky co nejvhodněji rozdělit, napřr. z hlediska umělecké kvality. Strategické rozhodování, co podpořit a co nikoli, není snadné. Snazší bývá změny nedělat. Proto většina pražských politických představitelů do strategií a plánování v kultuře př́iliš nezasahuje, pokud na ně není vyvíjen nátlak. Změny totiž mohou vyvolat negativní reakce a úspěšně je může ustát pouze ten, kdo mimo jiné opravdu bezpečně ví, jaké cíle chce naplňovat. V opačném prípadě je velká pravděpodobnost, že bude snadno ovlivnitelný zájmovými skupinami a zvolená strategie se tak začne hroutit jako v př́padě koncepcí radního Richtera.

Obecně diskutovaným tématem byla nezávislost odborníků v komisích. V uměleckém prostředí je nezávislost nemožná, což uznávají i sami odborníci, kteří jsou často stavěni před rozhodnutí, jakému projektu mají dát pro udělení podpory přednost. Naproti tomu politici dlouho nechtěli nechat rozhodování v rukou odborníků, protože oni mají mandát od voličů. Odpověd' na tuto otázku,

21 Zápis ze 40. zasedání Výboru pro kulturu a volný čas ZHMP, ze dne 4. 11. 2009 [online]. [cit. 2015-05-05]. Dostupné z: http://www.praha.eu/jnp/cz/o_meste/primator_a_volene_organy/ zastupitelstvo/vybory_zastupitelstva/archiv_zprav y_z_vyboru_zastupitelstva/volebni_obdobi_2006_2010/vybor_pro_kulturu_a_volny_cas/zapisy_zjednani/zapisy_z_jednani-zapis_ze_40_zasedani_vyboru_pro_kulturu.html.

Přiloha č. 1 usnesení Zastupitelstva hl. m. Prahy ze dne 3. 6. 2010 [online]. [cit. 2015-03-21]. Dostupné z: http://zastupitelstvo.praha.eu.

Ibid., s. 10. 
zda-li má o kultuře rozhodovat komise odborníků nebo politiků, uvádí Bohumil Nekolný: „Politické reprezentace mají jedinou legitimitu, a to: rozhodovat kompetentnè. A pokud kompetenci nemají, tak ji mají delegovat.“24

Velkým tématem byla hodnotící kritéria grantových žádostí. Sama politická reprezentace se neuměla jednoznačně rozhodnout, zda má být prioritou umělecká kvalita nebo návštěvnost. Ani kulturní veřejnost není v tomto ohledu jednotná. Soukromá divadla totiž většinou prosazují tabulkově vypočítané nárokové dotace, příp. hodnocení dle návštěvnosti. Všichni zástupci této skupiny mají jedno společné, nevidí rozdíl mezi zábavou a uměním.

Jedním z nástrojů, které mohou ve správném rozhodování pomoci, je evaluace, dlouhou dobu podceňovaná, ne-li př́mo ignorovaná. Hodnocení podpořeny'ch projektů a činností dává jasnou zpětnou vazbu nejen z hlediska hospodaření subjektu. Cennou zkušeností jsou i zjištění, na jaké umělecké úrovni se projekt odehrál a zda přináší hodnoty svým recipientům, což se ne vždy dá vyjádřit prostou tabulkou návštěvnosti. Nutno přiznat, že o reflexi podpořených projektů se do jisté míry snažil odbor kultury magistrátu výročními zprávami do roku 2004, ale od té doby $\mathrm{v}$ nich najdeme už jen jednoduché vyčíslení vynaložených prostředků. Zpětné hodnocení projektů je dnes zakotveno v kompetencích grantové komise. Zbývá tedy, aby činní političtí představitelé vzali v potaz výsledky hodnocení. Stejně tak by prospělo, kdyby při svých rozhodováních brali v potaz přijaté dokumenty. Často by totiž místo formulování nových deklarací a koncepcí stačilo respektovat dokumenty již schválené.

Magdalena Šmídová Turchichová (magdalenaturchichova@gmail.com), Ústav hudební vědy, Filozofická fakulta, Masarykova univerzita, Brno, CZ.

\section{ABSTRACT \\ THE DEVELOPMENT OF PRAGUE'S CULTURAL POLICY AFTER YEAR 2001}

This study deals with the development of Prague's cultural policy after year 2001. The first strategic document "The Concept of the Cultural Policy of Prague" was approved in 2006. Its updated version from year 2010 is valid until today and it reflects not only the consequences of culturally social development, but also aspects which are taken into account by institutes of the European Union. The "Grant Policy of Prague" document is an integral part of the cultural policy of the city. The document tries to indicate basic principles, goals, tools, plans and priorities of the city's cultural policy, and to capture circumstances of the entire process in which the political representation, members of the academic and cultural public, and the department of culture of the capital's town council all interacted together to form the policy.

\section{Key words}

concept of the cultural policy of Prague, grant policy of Prague, cultural policy

24 MATARASSO, François - LANDRY, Charles. Hledání rovnováhy: 21 strategických dilemat $v$ kulturni politice. Brno: Barrister \& Principal, 2015, s. 69. 


\section{Bibliography}

Analýza grantového ř́zení hl. m. Prahy pro oblast kultury [online]. In: Divadlo.cz. 26. prosince 2004, [cit. 2015-07- 26]. Dostupné z: http://host.divadlo.cz/art/clanek.asp?id=7123.

ČECHLOVSKÁ, Magdalena - NEPRAŠOVÁ, Veronika. Spor o granty poškozuje i nevinné neziskovky [online]. Hospodářské noviny. 7. září 2007, [cit. 2015-02-05]. Dostupné z: http://archiv. ihned.cz/c1-21972400-spor-o-granty-poskozuje-i-nevinne-neziskovky.

MACHALICKÁ, Jana. Arbitráž kvioli divadlìm nebude. Lidové noviny. 14. února 2008, s. 19.

MATARASSO, François - LANDRY, Charles. Hledání rovnováhy: 21 strategických dilemat v kulturni politice. Brno: Barrister \& Principal, 2015.

Otevřený dopis: Členům výboru kultury Zastupitelstva a ostatním zastupiteli̊m [online]. [cit. 201503-19]. Dostupné z: http://www.proculture.cz/cultureinfo/kulturni-politika-v-cr/praha/iniciativa-prazske-kulturni-sceny- usili-o-zmenu-navrhu-4-letych-grantu-mesta-prahy-pokracuje-510. html.

Př́loha č. 1 k usnesení Rady hl. m. Prahy č. 1707 ze dne 12. 10. 2004 [online]. [cit. 2015-03-10]. Dostupné z: http://rada.praha.eu.

Př́loha č. 1 k usnesení Zastupitelstva hlavního města Prahy č. 39/19 ze dne 29. 6. 2006 [online]. [cit. 2015-07-21] Dostupné z: http://zastupitelstvo.praha.eu.

Př́loha č. 1 usnesení Zastupitelstva hl. m. Prahy č. 28/43 ze dne 18. 6. 2009 [online]. [cit. 2015-0225]. Dostupné z: http://zastupitelstvo.praha.eu.

Př́loha č. 1 usnesení Zastupitelstva hl. m. Prahy ze dne 3. 6. 2010 [online]. [cit. 2015-03-21]. Dostupné z: http://zastupitelstvo.praha.eu.

Př́loha č. 2 k usnesení Zastupitelstva hlavního města Prahy č. 39/19 ze dne 29. 6. 2006 [online]. [cit. 2015-07-21]Dostupné z: http://zastupitelstvo.praha.eu.

Smlouvy o ES - články 87 a 88 . Dostupné z: https://www.uohs.cz/cs/verejna-podpora/podpora-de-minimis.html.

STÁT - MĚSTO - KULTURA: souhrn př́spěvků otevřené diskuze, kterou uspořádalo hl. $\mathrm{m}$. Praha ve spolupráci s Ministerstvem kultury ČR [online]. Ed. Mgr. Martin Kupka. Praha, Divadlo Archa: 1. 1. 2004, s. 9. [cit. 2014-06- 05] Dostupné z: http://host.divadlo.cz/box/clanek.asp?id=5418

Strategický plán hl. m. Prahy [online]. In: ENVIS - informační servis. 1999, s. 22, [cit. 201502-14]. Dostupné z: http://envis.praha-mesto.cz/\%28bm4grrjcztvnq545qbpbfp45\%29/default. aspx? clc $=\& I d o=5278 \&$ sh $=-1294051557$.

ŠMíDOVÁ TURCHICHOVÁ, Magdalena. Vývoj kulturní politiky v hl. m. Prahy po roce 2001. Brno, 2015. Diplomová práce. Masarykova univerzita. Fakulta filozofická. Vedoucí práce doc. Ing. František Svoboda, Ph.D. Dostupné online: http://is.muni.cz/th/180098/ff_m/

Usneseni Rady Zastupitelstva hl. m. Prahy č. 1402 ze dne 12. 12. 1995 [online]. [cit. 2015-03-12]. Dostupné z:http://rada.praha.eu.

Usnesení rady Zastupitelstva hlavního města Prahy č. 959 ze dne 7. 9.1999 [online]. [cit. 2015-0312]. Dostupné z: http://rada.praha.eu.

Usneseni rady Zastupitelstva hlavního města Prahy č. 234 ze dne 23. 2. 1999 [online]. [cit. 201503-12]. Dostupné z: http://rada.praha.eu.

Usnesení Vlády ČR ze dne 10. záŕí 2003 č. 902 o Programu státní podpory profesionálních divadela profesionálních symfonických orchestrů a pěveckých sborů [online]. 10. 9. 2003, [cit. 2015-0416]. Dostupné z: www.mkcr.cz/assets/umeni/Usnesen_vl_dy__-902.doc.

Zápis ze 40. zasedání Výboru pro kulturu a volný čas ZHMP, ze dne 4.11. 2009 [online]. [cit. 2015-05-05]. Dostupné z: http://www.praha.eu/jnp/cz/o_meste/primator_a_volene_organy/ zastupitelstvo/vybory_zastupitelstva/archiv_zpravy_z_vyboru_zastupitelstva/volebni_obdobi_2006_2010/vybor_pro_kulturu_a_volny_cas/zapisy_z_jednani/zapisy__ z_jednani-zapis ze_40_zasedani_vyboru_pro_kulturu.html. 
